\title{
The Need Textbook Writing of Children's Story Based on Character Education
}

\author{
Darsono $^{1}$, Winarno ${ }^{2}$, ST. Y. Slamet ${ }^{3}$
}

\begin{tabular}{l} 
ARTICLE INFO \\
\hline Article History: \\
Received 06.11.2017 \\
Received in revised form \\
17.01.2018 \\
Accepted \\
Available online \\
01.05.2018
\end{tabular}

ARTICLE INFO

\begin{abstract}
This study aims to develop textbooks to write children's stories based on the education character for fourth grade students of Muhammadiyah elementary school in Surakarta Indonesia, and also to improve students' skills in writing children's stories that are included the education character in it. The subjects of this study are students and teachers. The sampling technique uses purposive sampling. The methods of the data collection are through questionnaire, observation, interview, and documentation study, supported by Focus Group Discussion and field notes. The analysis data used in this study is techniques of peer-debriefing by analyzing in depth to the subject. The discussion of the result of the data analysis uses qualitative descriptive. The results of this study prove that; (1) based on the results of the exploratory study, it is proved that many elementary schools which do not have textbooks with special specifications to help students in writing children's stories, that's $100 \%$; (2) based on the results of the Focus Group Discussion it allows to be internalized the characters education into textbooks of children's stories; (3) the product prototypes of the textbooks in $w$ riting children's stories based on character education for fourth grade students of elementary school.
\end{abstract}

(C) 2018 IJERE. All rights reserved

Keywords:

The textbooks, writing story children's, character education.

\section{INTRODUCTION}

The textbook is a book written with the main purpose as a source of reference in learning activities that covers a particular field of science by meeting the rules of writing published scientific papers and disseminated. In addition, the use of the textbooks to assist the teachers in facilitating the delivery of the material which can help the students in the process of learning activities. So that, the students become easier in the process of achieving competence and able to know the learning activities well according to the national values (Sadhono, 2014, pp. 99- 106).

In the essence, the textbook is a medium learning of a certain discipline or knowledge. As a medium learning, the textbooks certainly contain teaching material in learning, so that the students are able to understand well. So, it needs the existence of the relevant textbooks in order to attract the interest and to encourage students in their ability in optimizing their talent and skill well. Novianto (2015:34-47) states that the things that need to be considered for the preparation of the textbooks which are taken from the closest to the students. It is begun from how to introduce the imagination of something then taught how to write based on what is perceived by what is seen and in what words to express. So that, it becomes a certain meaning and others can understand it.

The textbook is considered to be more effective and affordable. It can be practically used anywhere with the expected time and condition of the learning context. Now adays, the textbook is a tutorial that can be packaged in the form of manual or digital model with the principle of the use in scholarship. The technique of the play needs the help of the educators to reach the tar geted stage (Bruce Joyce et al, 2011:43).

The condition of the current textbook in the field has not shown a good availability. It can be proved by seeing the facts of the field documentation that the teachers in the process of learning activities uses a package book that has been published, besides the delivery techniques are done in a monotonous manner. So that, the students become unenthusiastic, less explorative, and to be lazier in growing imaginative ideas that lead to the level of thinking becomes weak primarily in composing and expressing ideas through writing activities which writing activity is often disregarded. So that, it becomes a mere formality in Indonesian language learning activities Mariatna (2015, pp. 21-37).

Corresponding e-mail: darsono.dar1@gmail.com, orcid.org/0000-0003-1553-5967 
Writing is a process of expressing both the thoughts of feelings they feel and the effort to express the ideas, findings, the virtues to be poured into a symbol of writing or essays that others can understand the intent of the submitted paper. Winarni and Slamet (2014:41) suggested that the process of writing as an essay includes four elements: ideas, speeches, guidance, and discourse. Ideas are topics or themes that will be presented. Speech is a form of disclosure of ideas. So that, the idea can be understood by the reader. Guidance is the orderliness of the arrangement and the preparation of ideas. Discourse is a mean of regulating the form of w ritten language that includes vocabulary, grammar, spelling and punctuation.

Lickona (2013: 72) suggests that characters are made up of thr ee interrelated parts of things: moral knowledge, moral feelings, and moral behavior. These three elements are very important to run a moral life. Those elements arefactors of moral maturity. Character is a person's good self and positive attitude tow ards self and the surrounding environment that can be formed early from personal factors also with the help of a characteristic environment. A characteristic environment can be formed within a family, community and school. It Starts from the self-control of compassion and mutual love that is grown in the psyche of students (Supriati and Harminto, 2015: 34-47).

Moral education and character is used for strengthening human relationships within a framew ork of a broad organizational system that is state or government. The arrangement is clustered and intertwined with each other, then it takes commitment in the process of reaping the success of character education. The child's learning age will be more decisive in the future when compared to the present period due to the less optimal pattern of past character formation (Michael J. Richardson, 2015, pp. 63-77).

The innovation in this research is to produce prototype textbook in writing story of children based on the character education. This prototy pe does not just load the w riting skill but also comes with animation of images and integrated with the character values. Through the textbooks in writing children's stories based on the character education can be explorative and attractive to innovate in conveying the proces $s$ of learning activities in the future (Andreas J Pieter, 2016, pp. 42-64).

The Benefits of the learning activities to the students is that the students are easy to find the imaginativeideas that can be poured in a good writing and grow the value of chara cters in it.So, through the right delivery method, it can prove that children can imagine the reality. There will be a good interaction stimulus among children, teachers and environments that can be shaped like books, learning media and atmosphere, and good conductivity (Heintz and Svensso, 2015, pp. 15-28).

From the description above, it can be concluded that majority of Muhammadiyah Elementary Schools in Surakarta City still use instructional book that can be categorized as non-renew able publication. So that, it needs an innovation of textbook development. In this research, there is a solution to solve the problem. The solution is by using innovation development of a textbook product in writing children's story based on the character education which focuses on the aspect of children's story w riting skills in Indonesian language learning by integrating the character education. The researcher hopes that it can provide the main benefits to the students' writing skills. It is memorable and full of meaning based on the planting of a good character.

\section{Situation of the Problem}

There are some problems that arise and often encounter in elementary school. One of them is related to the students' writing. It is because of less attention from all parts, so most of the students just write as a regular w riting without any clear directions. So that, the result of students' $w$ riting becomes less meaningful and has no meaning and important meaning of the text. It can also be seen from the aspect of the students who do not write on the right media. It can damage an arrangement of writing's composition. In addition, the reflection of the character values in each student's writing is not visible, so it is feared becoming a decline in the character of the future of the students.

\section{Aim of the Study}

Aim of the present study is to advance generally basic of primary education in Indonesia, with makes creating of the textbooks writing children's story based on the character education. İn order that is the increase skills in the writing stories and than also accompanied character education in every soul student. With the textbook writing story-based children's character education can also facilitate teachers in 
transfering know legde to the children's about writing story lessons with interesting. So the ultimate goals of the end is that all parties can benefit from a children's story based educational us this textbook.

\section{METHOD}

This research uses tecnique data collection methods in this preliminary study were conducted through a questionnaire and observation by interviewing and analysing field document. The results of the survey in Elementary School became the basis of the process of developing the textbooks according to the specifications that is expected by the Muhammadiyah Elementary Schools of Surakarta. These data include; documents or supporting tools for writing stories, findings in the Muhammadiyah Elementary Schools about the condition of textbooks used so far, the availability of the appropriate textbooks in the school, the learning process, and the implementation of the character values inclusion during the learning activities.

Based on the explanation above, it can be concluded that the data collections used in this research are by using: interviews, observation, questionnaires, and document analysis. Furthermore, the detailed and in-depth data analysis with peer-debriefing technique is used to test the credibility of the data and fact finding both from subject or object in previous research process. The next analysis is described with descriptive qualitative. For the process of determining the product to the level of feasibility, the role of textbooks' experts, language experts and material experts is required to provide input or suggestion and determine the feasibility of the textbook product which will be used in Muhammadiyah Elementary School Surakarta.

\section{Material}

The data collection methods in this preliminary study were conducted through a questionnaire and observation by interviewing and analysing field document. The results of the survey in Elementary School became the basis of the process of developing the textbooks according to the specifications that is expected by the Muhammadiy ah Elementary Schools of Surakarta. These data include; documents or supporting to ols for writing stories, findings in the Muhammadiyah Elementary Schools about the condition of textbooks used so far, the availability of the appropriate textbooks in the school, the learning process, and the implementation of the character values inclusion during the learning activities.

\section{Data Analyses}

This research uses qualitative descriptive approach by exposing the fact elements in the field. The research procedure in the preliminary study embodies a draft or textbook for teaching children's story based on the character education for the fourth grade students of elementary school in Surakarta. The basic step begins with the analysis of field needs and problems in the field. The design of solutions will be arranged in a textbook product in writing a children's story based on the character education.

The analysis of the data uses peer-debriefing technique by doing deep data digging to the main. The target in this research is teacher and student. The sample of the subjects in this study involve several Muhammadiyah Elementary Schools in Surakarta. The way of sampling is done by using purposive sampling technique. It is begun through exploratory studies related to the condition of books that have been used in learning to write stories. Further analysis of the need for the textbooks to write children's stories based on the character education in Muhammadiyah Elementary Schools, Surakarta, and the learning process mechanism are applied in Muhammadiyah Elementary Schools of Surakarta. And the last, it is used to know the pattern of the implementation of the character values of Muhammadiyah Elementary school students Surakarta.

\section{FINDINGS}

Based on the findings and observation above it can be concluded that Muhammadiyah Elementary School in Surakarta which is calculated based on the location where Muhammadiyah Elementary school studied show s with the percentage of $100 \%$ there is no specific textbook used to teach story writing based on the character education. The number of the textbooks that has been used is not sufficient for the students when it is viewed from the ratio with the number of the students. Because the amount of the textbook's availability is less than the number of the students. The textbooks that have been used are mostly in old edition. The description of the material in the textbook that has been used in relation to the writing of the 
story has not been specified in improving students' writing skills and integrating character education. Researcher assesses the need for the relevant textbook development related with the writing of children's stories based on the character education. It is an effort to increase students' ability in writing character oriented stories.

The result interview is used to collect some answers from the fourth grade teachers at the Muhammadiyah elementary school in Surakarta, related to the writing of the story. The teachers have difficulty in teaching methods to find ideas for students to be more imaginative and creative. The teachers also have difficulty in inculcating the value of the character through the activities of writing stories. So far the delivery method of the material uses a simple book without any innovation in delivering the material.

The teachers complained about the difficulty in establishing skilful attitudes in writing properly because students tend to be monotonous or passive during the learning activities of writing. So that the students' writing is judged by others. It causes the students' creativity to be less optimal. In addition, the teachers complain about the difficulty of instilling a characteristic soul in students through appropriate character education that is expected.

From the results of interview with teachers, there is a statement that the teacher has tried to inculcate the value of the character in learning activities maximally. How ever, it is differentiated with the expected precisely based on the observation activities during research activities that is proved to be far from the stage of internalization of proper character education. So the teacher only gives a statement for suggestion that less meaningful and touches the student's heart.

The next method is to spread the questionnaire to a number of students. So that the results can be obtained to answer. It can be analysed and seen from the following percentage:

Table 1

Questionnaire of the data needs of the students.

\begin{tabular}{|c|c|c|c|c|c|c|}
\hline \multirow[t]{3}{*}{$\begin{array}{l}\text { Num } \\
\text { ber }\end{array}$} & \multirow[t]{3}{*}{ Name of School } & \multicolumn{4}{|c|}{$\begin{array}{l}\text { The statement of students who said agree in } \\
\text { the class }\end{array}$} & $\begin{array}{l}\text { Total } \\
\text { students }\end{array}$ \\
\hline & & $\begin{array}{l}\text { The } \\
\text { importance }\end{array}$ & $\begin{array}{l}\text { The } \\
\text { importanc }\end{array}$ & $\begin{array}{l}\text { The } \\
\text { importanc }\end{array}$ & $\begin{array}{l}\text { The } \\
\text { importanc }\end{array}$ & $\begin{array}{l}\text { in the } \\
\text { class }\end{array}$ \\
\hline & & $\begin{array}{l}\text { of the } \\
\text { textbooks }\end{array}$ & $\begin{array}{l}\text { e of } \\
\text { learning } \\
\text { Indonesian }\end{array}$ & $\begin{array}{l}\text { e of } \\
\text { writing } \\
\text { activities }\end{array}$ & $\begin{array}{l}\text { e of } \\
\text { character } \\
\text { education }\end{array}$ & \\
\hline 1 & $\begin{array}{l}\text { Muhammadiyah } \\
\text { elementary school A }\end{array}$ & 30 & 32 & 29 & 28 & 34 \\
\hline 2 & $\begin{array}{l}\text { Muhammadiyah } \\
\text { elementary school B }\end{array}$ & 29 & 34 & 32 & 31 & 34 \\
\hline 3 & $\begin{array}{l}\text { Muhammadiyah } \\
\text { elementary school C }\end{array}$ & 37 & 34 & 31 & 32 & 37 \\
\hline 4 & $\begin{array}{l}\text { Muhammadiyah } \\
\text { elementary school D }\end{array}$ & 32 & 32 & 29 & 30 & 32 \\
\hline 5 & $\begin{array}{l}\text { Muhammadiyah } \\
\text { elementary school E }\end{array}$ & 36 & 35 & 33 & 34 & 36 \\
\hline
\end{tabular}

Seeing from the student questionnaire data table 1analysis of the student needs to the importance of the textbooks in improving the ability in w riting stories based on the character education. If it is calculated about the percentage of the student interest is as follows:

Percentage of the formulas: $\overline{\mathrm{X}}=\frac{\sum X}{N} \times 100$ 
Darsono, Winarno,\& ST. Y. Slamet (2018). The need textbook writing of children's story based on character education. International Journal of Educational Research Review,3(2),1-8.

$\mathrm{X}=$ the Average ; $\sum X=$ the Number of Scores obtained; $\mathrm{N}=$ the Number of students

Table 2

The Percentage of the requirement analysis of student's textbook

\begin{tabular}{|c|c|c|c|c|c|}
\hline \multirow{2}{*}{$\begin{array}{l}\text { Num } \\
\text { ber }\end{array}$} & \multirow[t]{2}{*}{ Name of the School } & \multicolumn{4}{|c|}{ The Percentage number of the students who agree } \\
\hline & & $\begin{array}{l}\text { The } \\
\text { importance } \\
\text { of the } \\
\text { textbooks }\end{array}$ & $\begin{array}{l}\text { The } \\
\text { importance of } \\
\text { learning } \\
\text { Indonesian }\end{array}$ & $\begin{array}{l}\text { The } \\
\text { importance } \\
\text { of the story } \\
\text { writing }\end{array}$ & $\begin{array}{l}\text { The } \\
\text { importance } \\
\text { of the } \\
\text { character } \\
\text { education }\end{array}$ \\
\hline 1 & $\begin{array}{l}\text { Muhammadiyah } \\
\text { elementary school A }\end{array}$ & $88,23 \%$ & $94,11 \%$ & $85,29 \%$ & $82,35 \%$ \\
\hline 2 & $\begin{array}{l}\text { Muhammadiyah } \\
\text { elementary school B }\end{array}$ & $85,29 \%$ & $100 \%$ & $94,11 \%$ & $91,17 \%$ \\
\hline 3 & $\begin{array}{l}\text { Muhammadiyah } \\
\text { elementary school C }\end{array}$ & $100 \%$ & $91,89 \%$ & $83,78 \%$ & $86,48 \%$ \\
\hline 4 & $\begin{array}{l}\text { Muhammadiyah } \\
\text { elementary school D }\end{array}$ & $100 \%$ & $100 \%$ & $90,62 \%$ & $93,75 \%$ \\
\hline 5 & $\begin{array}{l}\text { Muhammadiyah } \\
\text { elementary school E }\end{array}$ & $100 \%$ & $97,22 \%$ & $91,66 \%$ & $94,44 \%$ \\
\hline & e Average percentage & $94,70 \%$ & $96,64 \%$ & $89,09 \%$ & $89,63 \%$ \\
\hline
\end{tabular}

Based on the result of the accumulation of high percentage of the questionnaire above, the majority above $80 \%$, it is categorized that overall Muhammadiyah Elementary School which is being a sample of the research states requirement of the presence of the textbook writing character-based children's story for fourth grade students of Elementary School. This indicates that most Muhammadiyah elementary schools and others also need the presence of children's character-based story-w riting books.

In accordance with the results of the analysis, the results of interviews both teachers and students, supported by student's questionnaires and the percentage of the students' need for the textbooks in writing a story has been known then it can be used for the basis of drafting the prototype book model teaching children's story-based story character education. Then, the researchers do the next stage of preparing the initial draft or prototype textbooks to write children's stories based on character education for fourth grade students of Muhammadiyah Junior High School Surakarta by seeing from the results of the needs analysis aspect and the importance of the textbooks in writing children's stories based on the character education.

\section{RESULT, DISCUSSION, AND SUGGESTIONS}

The improvement of the character education of the students in this research can be seen when the students expressing their opinions. The attitudes of discipline are obedient with the rules and respect the time. Honest attitude is shown with friendly and humble mannered behaviour, such as not cheating. Responsibility is shown by behaviour in taking risks that against decisions or answers that have been exposed.

Through a series of analysis and observation process, it can be concluded that the importance of the presence of the textbooks in writing children's story-based character education is to improve the children's story writing that includes student character values. So that the prototype textbook in writing children's story-based character education is able to answer the needs. It can also optimize the ability of the students to $w$ rite stories as well as increasing the character education. The initial prototy pe preparation process is based on the results of the needs analysis and the real conditions in the field, such as the participation of the 
teachers and the experts. The next stage is the preparation of the textbooks in writing children's stories based on the character education. The final product will be used for the students of Muhammadiyah Elementary School in Surakarta.

The structure and the process of descriptive qualitative research refer to the present aspect based on the findings of the problems encountered in the field. It can be seen that there is no available textbook with special specifications in writing children's stories based on the character education. So this research can bring benefits for the advancement of education in general. According to Stanford A. Jasson (2017: 700-711), educational research can produce a creation or product creation that is renewable to bring the impact in facilitating to deliver the information faster that will be accepted by students.

Related to the research process in preparing the textbook is the review process and input by all experts. In the same case, there is similar opinion Skaggs \& Bodenhorn (2012, pp. 82-114) which states that the product of validation process until the birth of a competitive product requires patience with good character relations among others, consistency in applying the principle, respecting to others, defending truth, justice and responsibility when facing behaviour and ethical choices.

The preparation of the textbooks as a medium learning requires a detailed review and reviewers. So that the result of the product is really appropriate and useful. This is consistent with the opinion (ZW Chen and $\mathrm{YL} \mathrm{Xu}, \mathrm{Q}, 2015$, pp. 383-391) which states that the quality of the textbooks is determined from the process of arranging them up to a thorough assessment process to finish and print for the extent which following a series of trials to make sure that the textbook product is really high quality.

In the process of preparing the textbooks in writing children's stories based on the character education, it requires a series of processes and improvements. In line with the results of the research conducted by Mumbrita \& Sukardi (2010: 74-90) that suggests the process of the product improvement requires the process of the implementation periodically from the beginning up to the evaluation that conducted with experts or other experts to provide suggestions as an input that can build the appropriate product revision for the next. Then, the next step is tested by the evaluation and revision to get final product results. Next, to find out how much the maximal results from the series of improvements the product should be with a series of testing stages.

The optimization of learning through the textbooks in writing children's stories based on the character education is by prioritizing students' activity. For example: putting forward the brilliant ideas of students accompanied by the inculcation of the personal character values of the students to produce outputs as desired. It is proven in this study and in line with research conducted by Kessler Craigh (2013: 79-95) which obtained that the results of amazing student's creativity are began from the simple idea of the students who always try to practice and create according to their interests and ability in assembling something, drawing, writing and all experiments or practicum which facilitated by the teacher, learning media, and learning environment which supports.

Another study conducted by Suyatiningsih \& Isniatun (2016: 48-61) suggests that continuous learning with a learning approach that includes innovation and able to provide space for creativity and motivation to the students that will facilitate the planting of character values. All elements and other supporting aspects are done together. So that the results obtained increasing the moral of the students who improved.

The research findings Clayton T. Wukich (2016, pp 381-406) state that the established community network originates from relationships between individuals of character to work together and supported from all appropriate infrastructures. It has relation with this research that is in the aim to create a superior generation full of good character. The media or appropriate learning resources that is the textbooks to write children's stories based on the character education requires in improving students' skills in w riting children's stories and the cultivation of the character education of the students.

The result of the research in the form of prototy pe textbook in w riting the story of the children based on the character education can optimize the students' skill in w riting the children's story. Besides it can bring meaningful change in character aspect that becomes more positive character even better. In a study conducted by Matthews, \& Robert (2012: 386-399) states that the use of the textbook media is one of the 
sources of science in proper learning. It can bring the dominant influence to the child's life with the learning world environment in accordance with the development and maturity that is harmony with instructional goals. So that learning objectives can be achieved.

Based on the descriptions, references or relevant research and supported from the results of the data collection and observation above, it can be asserted that the prototype of the textbooks in writing children's stories based on the character education is expected to optimize the aspects of students' story writing skills and be able to optimize the inculcation of the values of the character education to students. Thus, the prototype of the textbooks in writing children's stories based on the character education is said to be acceptable existence and can be used in other schools to be more useful.

The results of the study can be concluded as follows: In the initial exploratory study it was found the fact that the fourth grade students in Muhammadiyah Elementary School Surakarta have not special of specification book in writing the story of the children based on character education. A number of information collected from the students and the teachers is obtained by data analysis needs of the importance of textbooks in writing children's stories based on character education as long as it is expected. The students and the teachers use a special specification book in teaching how to write appropriate stories according to the level of student development, so to facilitate the students and the teachers in the process of learning activities of children's story w riting is oriented to the character education.

Based on the results of observation activities in the field and supported by the results of several data collection techniques and conducted FGD with experts, it is formulated prototy pe textbooks in writing stories of children based on the character education. The prototypes of the textbooks in writing children's stories based on the character education can improve students' skills in writing of the children's stories and enhance the inculcation of students' character values.

The research process cannot be separated from the role of advocates, especially some elementary schools in Surakarta which are directly involved in the study. The respondents in the field such as the teachers and students continue to give the information to build a construct of thought for the researcher, as well as the experts as the development valuator of creating a major book in the assessment process

\section{REFERENCES}

Abidin, Y. (2012). Learning Indonesia language based on character educational. Bandung: PT Refika Aditama.

Andreas, J. P. (2016). Modalities and development society for kid's to globalities good program. International Journal Of Science Education, 8 (3). 42-64.

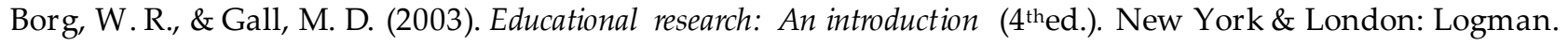

Bruce Joyce, dkk. (2011). Models of teaching. Yogyakarta: Pustaka belajar

Clayton T. Wukich. (2016). The formation of transnational character education in network society. Journal International Mangement Public. 20 (3). 381-406.

Harlensen, E.A. (2014). Inspired for good lives a young humanity program. Journal educational and science of knowledgment, 8(4), 118-135.

Kessler, Craigh. (2013). Student-Initiated attention to form in wiki-based colaborative writing. Language Learning and Technology.13(3), 79-95.

Lickona, Thomas. (2013). Educating for character. educating for character. Educating For Character. Jakarta: Bumi Aksara

Mariatna. (2015). Basics of the teaching and constraint learning process teachers facing in teaching scientific writing. Jurnal Kependidikan, 3(2), 21-37.

Maria Heintz dan Kertsin Svensso. (2015). Complitical of interaction the children making powerfully of our imagination. Language Learning and Technology,7(3), 53-67. 
Darsono, Winarno,\& ST. Y. Slamet (2018). The need textbook writing of children's story based on character education. International Journal of Educational Research Review,3(2),1-8.

Marzuki \& Yoga A.F. (2016). The role and parenting patterns to student moral actions in globalitation. Jurnal Kependidikan. 46(2), 67-82.

Matthews, Robert. (2012). Constructivism philosophical educationaly examined. International Educational Journal,6(3),386-399.

Mumbrita, S \& Sukardi. (2010). Maping potential and development humanities. Jurnal Kependidikan. 40(1), 7490.

Muslich, Masnur. (2014). Character education: To answering the multidimensional crisis challenges. Jakarta: Bumi Aksara.

Novianto, A., \& Mustadi, A. (2015). Analysis lesson material and technical integrated environment scientific approach, with authentic assessment in elementary scholl. Jurnal Kependidikan, 45(1), 10-15..

Supriati \& Harminto. (2015). Exchanges social and political ethic in globalitation. Jurnal Kependidikan, 7(2), 34-47.

Suyatiningsih \& Isniatun M. (2016). Scientific approach-based learning integrated character values for students in elementary school. Jurnal Kependidikan. 46(1), 48-61.

Skaggs, G., \& Bodenhorn, N. (2012). Relationships between implementing character education, student behavior, and student achievement. Journal of Advanced Academics, 18(2), 82-114.

Standford A. Jasson. (2017). Curicula and effective learning comprehension. Journal of Education and Work. 30(9), 700-711.

Sukmadinata, Nana Syaodih. (2012). Educational research methods. Bandung:PT Remaja Rosdakarya.

Winarni, Retno dan Slamet. (2014). Writing integrative thematic stories based on character education. Surakarta: UNS Press

Z. W. Chen, Y. L. Xu, Q. Li, D. J. Wu. (2015). Analysis material of long teaching to student loadings knowledge. International Journal of Bridge Engineering and Education,16 (3),383-391. 